\title{
PENGEMBANGAN HIPOTETIK BUKU BANTUAN DIRI TENTANG BAHAYA MEROKOK
}

\author{
Awaluddin Tjalla ${ }^{1}$ \\ Gantina Komalasari \\ Elmira Asharika ${ }^{3}$
}

\begin{abstract}
Abstrak
Penelitian ini bertujuan untuk mengembangkan sebuah buku bantuan diri tentang bahaya merokok guna memberikan informasi pada mahasiswa/i tentang bahaya dan dampak dari merokok. Penelitian ini menggunakan metode Penelitian dan Pengembangan (Research and Development) yang dikembangkan oleh Borg and Gall. Penelitian yang dilakukan tergolong dalam penelitian $R \& D$ skala kecil (Small-Scale $R \& D$ ), karena penelitian yang dilakukan menggunakan beberapa tahapan saja yaitu penelitian dan pengumpulan informasi; perencanaan; pengembangan format produk awal; validasi produk awal; dan revisi produk. Pada tahap validasi, produk dinilai oleh tiga validator ahli yaitu validator ahli media, validator ahli materi, validator ahli bahasa, serta dinilai oleh validator pengguna yaitu mahasiswa. Penelitian ini menghasilkan sebuah buku bantuan diri yang berjudul "\#mahasiswatanparokok". Hasil persentase kelayakan buku dari masing-masing validator yaitu validator ahli media menilai sebesar $80,8 \%$ (sangat layak), validator ahli materi menilai sebesar 72,2\% (layak), validator ahli bahasa menilai sebesar $86,1 \%$ (sangat layak), serta validator pengguna yaitu mahasiswa menilai sebesar $87,2 \%$ (sangat layak). Kesimpulan dari penelitian ini yaitu buku bantuan diri tentang bahaya merokok dikategorikan sangat layak dengan rata-rata persentase sebesar $80.5 \%$. Diharapkan buku bantuan diri tentang bahaya merokok dapat diujicobakan sehingga buku ini efektif digunakan, serta diharapkan penelitian ini dapat dilakukan di Universitas lainnya.
\end{abstract}

Kata Kunci: Bantuan Diri, Buku Bantuan Diri, Rokok, Bahaya Merokok, Mahasiswa

\section{HYPOTHETICAL DEVELOPMENT OF SELF HELP BOOK ABOUT DANGERS OF SMOKING}

\begin{abstract}
This research aims to develop a self help books about the dangers of smoking. This research used the method of research and development by Borg and Gall. Research conducted in R\&D belongs to the small scale, because the research was done using multiple stages only, namely (1) Research and Information Collecting; (2) Planning; (3) Develop Premilinary From of Product; (4) Premilinary Field Testing; and Main Product Revision. At this stage of validation, the product is assessed by three experts, namely the media expert, content expert, linguists expert, as well as rated by users i.e. collage students. This research resulted in a book help self titled "\#mahasiswatanparokok". The results of the feasibility of the percentage of each validator that is media experts assessed the validator of $80.8 \%$ (very decent), material experts assessed the validator of 72,2\% (worth), linguist validators assessed of $86.1 \%$ (worth), as well as validator

\footnotetext{
${ }^{1}$ Dosen Program Studi Bimbingan dan Konseling FIP UNJ, gantina.komalasari2803@gmail.com

2 Dosen Program Studi Bimbingan dan Konseling FIP UNJ, awaluddin.tjalla@yahoo.com

${ }^{3}$ Mahasiswa Program Studi Bimbingan dan Konseling FIP UNJ, elmira.asharika.kuliah@gmail.com
} 
users who were student assessed $87.2 \%$ (very decent). The conclusions of this research that is self help books about the dangers of smoking is categorized very well worth $80.5 \%$ percentage to the amount. Self help books about the dangerous of smoking is expected to be tested so the book is effectively used, as well as this research is expected can be done at other Universities.

Keywords: Self Help, Self Help Book, Cigarette, Dangers of Smoking, Collage Student.

\section{PENDAHULUAN}

\begin{abstract}
Manusia seringkali dihadapkan pada berbagai permasalahan. Mulai dari permasalahan yang bersifat ringan dan dapat cepat diselesaikan sampai dengan masalah berat yang menuntut waktu, tenaga dan pikiran lebih dalam upaya penyelesaiannya. Permasalahan tidak hanya menghampiri orang dewasa tetapi menghampiri setiap orang, tak terkecuali remaja ataupun remaja yang akan menuju dewasa. Menurut Fincham \& Ming (2011), fase menjelang dewasa merupakan konsepsi baru masa perkembangan untuk periode akhir remaja, dengan fokus pada usia 18-25 tahun. Fase menjelang dewasa ditandai dengan keinginan individu untuk mengeksplorasi diri dengan berbagai pilihan dirinya sendiri. Individu menjadi lebih independen dan tidak bergantung pada orangtua, namun belum sepenuhnya dapat berkomitmen dan bertanggung jawab sebagai orang dewasa. Pada fase ini individu merasa dirinya berada diantara fase remaja dan dewasa awal.
\end{abstract}

Fase menjelang dewasa termasuk didalamnya periode usia mahasiswa. Mahasiswa menghadapi berbagai macam tuntutan-tuntutan yang harus dipenuhi. Pendapat ini didukung dengan pernyataan Santrock bahwa salah satu unsur kesuksesan mahasiswa di perguruan tinggi yaitu menciptakan hubungan sosial yang baik, terutama dengan teman sebaya. Strang (dalam Chien, 1998), salah satu kesulitan mahasiswa yaitu mengenai permasalahan sosial pada penyalahgunaan zat adiktif khususnya rokok.

Na'imah (2016) melakukan penelitian pada 30 mahasiswa S1 Universitas Negeri Jakarta mengenai permasalahan sosial. Didapatkan 28 orang diantaranya menyatakan bahwa mengetahui masalah sosial merupakan hal yang penting. Hal tersebut menjadi bahan introspeksi dan sebagai bahan evaluasi diri agar permasalahan tidak semakin bertambah dan tidak mengganggu. Selain itu hasil penelitian Na'imah menyatakan bahwa dari 18.138 mahasiswa dengan teknik pengambilan sample secara insidental, sebanyak 376 responden merupakan penyalahguna bahan adiktif (Perokok) memiliki persentase sebesar 2,79\%.

Menurut Ellizabet (2010), rokok merupakan suatu benda yang tentu saja tidak asing bagi manusia. Bagi sebagian orang, rokok merupakan sesuatu yang sangat menyenangkan, menguntungkan, bahkan menenangkan. Namun, sebagian orang lainnya berpendapat bahwa rokok sangat merugikan. Kerugian ini tidak hanya dialami oleh perokok, tetapi orang-orang yang ada di dekat perokok pun (perokok pasif) ikut merasakan dampaknya.

Perokok pasif adalah orang yang ikut menghirup asap rokok tetapi tidak merokok. Penelitian di Amerika Serikat menunjukkan kematian akibat asap rokok pada perokok pasif lebih tinggi dibandingkan dengan kematian akibat polusi udara lainnya. Sekitar 4.000 orang perokok pasif meninggal setiap tahun karena kanker paru (Djauzi, 2009). Banyak orang yang ingin menyingkirkan rokok, namun mungkin hal ini tidak mudah, karena rokok merupakan bagian yang sepertinya mendarah daging bagi penikmatnya. Salah satu alasannya menganggap rokok akan menambah teman dan terlihat lebih atraktif. 
Ellizabet (2010) mengatakan bahwa kecanduan pada rokok disebabkan oleh zat nikotin. Seiring waktu, sesorang menjadi kecanduan secara fisik dan emosional terhadap nikotin, serta menimbulkan perasaan menyenangkan, bertindak seperti orang depresi lantaran menghalangi aliran informasi antara sel saraf. Pentingnya pengetahuan tentang rokok dan bahaya rokok, karena dampak rokok tidak hanya dialami oleh seseorang yang benarbenar memiliki kebiasaan merokok (perokok aktif) tetapi juga merugikan seseorang yang tidak memiliki kebiasaan merokok, namun harus menghisap asap rokok yang dihembuskan oleh orang lain yang kebetulan ada di dekatnya (perokok pasif).

Rokok kini termasuk satu diantara 10 penyebab kematian orang dewasa di dunia. Peringkatnya cenderung naik sampai tahun 2030 karena diperkirakan ada 10 juta kematian pertahun (Adiyanty, 2005). Notoatmodjo (2003) menyatakan bahwa pemahaman atau pengetahuan sesorang tentang rokok akan menentukan seseorang untuk menjadi perokok atau tidak. Menurut Wullur (2008), pengaruh iklan tentang rokok sering menimbulkan pemahaman atau pengetahuan yang salah tentang rokok. Pemahaman atau pengetahuan yang salah tentang rokok ini selanjutnya akan mendorong terbentuknya sikap yang salah tentang rokok dan pada akhirnya terjadi proses aplikasi dimana seseorang menjadi perokok.

Merokok adalah kebiasaan yang tidak sehat, namun di Indonesia jumlah perokok cenderung meningkat. Menurut survey WHO dalam buku Judith Mackay yang berjudul "The Tobacco Atlas" (2002), yaitu hampir satu miliar laki-laki di dunia ini merokok, sekitar 35\% dari orang-orang di negara-negara maju dan 50\% dari orang-orang di negara berkembang. Who juga melakukan survey pada wanita di dunia dan hasilnya 250 juta wanita di dunia adalah perokok sehari-hari, sekitar $22 \%$ dari wanita di negara berkembang. Tidak hanya jumlah perokok di dunia tetapi Mackay (2002) juga menjelaskan jumlah perokok di Indonesia yaitu sebanyak 212 juta orang. Kemudian jumlah perokok tersebut dibagi berdasarkan usia, yaitu perokok dewasa dan perokok remaja. Jumlah perokok dewasa di Indonesia sebesar 66,6 juta orang, yang terdiri dari 59\% laki-laki dan $3,7 \%$ perempuan. Sedangkan jumlah perokok remaja yang aktif sebesar 46,7 juta orang, yang terdiri dari $38 \%$ laki-laki, $5,3 \%$ perempuan dan perokok remaja yang pasif sebesar 133,6 juta orang. Di Indonesia yang mengkonsumsi rokok pertahunnya sebesar 1.742 orang dan tidak ada satu orang pun yang ingin berhenti merokok sampai pada tahun 2002 .

Penelitian pada 86 mahasiswa D3 Fakultas Teknik UGM Angkatan 2008 yang menggunakan alkohol, rokok dan zat adiktif yaitu $43 \%$ mahasiswa melakukan penyalahgunaan alkohol, rokok dan zat adiktif dengan alasan coba-coba dan terpengaruh teman.

Self-help dapat dijadikan sebagai salah satu cara alternatif bantuan diri yang dilakukan secara mandiri terutama bagi individu yang tidak berani atau malu untuk mengungkapkan atau menceritakan hal yang sedang dialaminya terhadap orang lain di sekitarnya terutama bagi mahasiswa yang menganggap relasi dengan lingkungan sosial sangat penting. Bergsma (2007) menjelaskan self-help merupakan "tindakan membantu atau memperbaiki diri sendiri tanpa bantuan orang lain" sehingga dalam konteks buku psikologi, membantu diri sendiri merupakan bentuk mengatasi masalah pribadi atau emosional seseorang tanpa bantuan dari seorang profesional.

Berdasarkan 11 studi dengan peserta lebih dari 21.000 perokok, self help terbukti memiliki manfaat serta kemungkinan berhenti meningkat sekitar 20\%. Self help lebih bermanfaat dan efektif dibandingkan dengan tatap muka singkat atau nasihat (Boyce et.al., 2014). 
Menurut Linda Farriz Kurtz (2007), kegiatan self help dapat dilihat sebagai proses bantuan kepada diri sendiri yang memiliki misi yang jelas untuk membantu mengubah beberapa aspek dalam diri sendiri. Menurut Gould dan Clum dalam Lawrence (2008), selfhelp berbasis media merupakan alternatif baru bagi individu untuk mengelola dirinya baik dengan masalah medis maupun psikologis yang dapat dilakukan dengan salah satunya menggunakan buku. Self-help book atau biasa disebut buku bantuan diri memiliki tujuan untuk membimbing dan mendorong klien untuk melakukan perubahan, sehingga meningkatkan manajemen diri, bukan hanya memberikan informasi saja.

Banyak manfaat yang diperoleh dari buku bantuan diri, seperti biaya buku lebih rendah dibandingkan berkonsultasi, buku mudah dibawa dan dibaca dimanapun dan kapanpun, dan kerahasiaan masalah terjaga karena kita tidak perlu bercerita pada siapapun, serta yang terakhir buku self-help cukup sering menjadi penjualan dan pembelian terbaik karena dengan membaca buku tersebut dapat memberikan kesempatan bagi pembacanya untuk menjadi bagian dalam buku tersebut.

Salah satu penjualan buku bantuan diri di Australia yang berjudul "Quit Book". Menyediakan informasi tentang efek berbahaya dari Merokok dan metode berhenti perokok. Quit Book ditulis oleh Quit Victoria. Pada tahun 2010 sebanyak 335.000 buku dicetak, sebuah survei Victoria tahun 2010 menemukan bahwa $82 \%$ ditemukan sangat mudah untuk memahami, relevan dan bermanfaat dan $94 \%$ akan merekomendasikan hal ini kepada orang lain (Scollo \& Winstanley, 2015).

Selain itu, masalah merokok juga sangat penting bagi mahasiswa Universitas Negeri Jakarta karena merupakan salah satu perguruan tinggi negeri yang menghasilkan atau mencetak calon pendidik atau calon guru maupun non-keguruan. Calon guru yang nantinya akan menjadi guru merupakan komponen penting dalam pendidikan karena guru memiliki peranan besar dan strategis, guru yang digugu dan ditiru juga berhadapan langsung dengan peserta didik untuk memberikan ilmu sekaligus mendidik dengan nilai-nilai positif melalui bimbingan dan keteladanan. Hal itu lah yang mengharuskan guru memiliki kompetensi kepribadian yang baik agar menghasilkan generasi masa depan yang baik pula.

\section{ACUAN TEORITIK}

\section{BANTUAN DIRI (SELF - HELP)}

Dalam kamus psikologi, kata self memiliki arti "diri (sendiri), atau keseluruhan yang dirasa dan diyakini benar oleh seseorang mengenai dirinya sebagai seorang individu". Bergsma (2007) menjelaskan bantuan diri merupakan "tindakan membantu atau memperbaiki diri sendiri tanpa bantuan orang lain" sehingga dalam konteks buku psikologi, membantu diri sendiri merupakan bentuk mengatasi masalah pribadi atau emosional seseorang tanpa bantuan dari seorang profesional. Menurut Kurtz (2007), proses bantuan kepada diri sendiri yang memiliki misi yang jelas untuk membantu mengubah beberapa aspek dalam diri sendiri adalah bantuan diri. Menurut Gould dan Clum dalam Lawrence (2008), bantuan diri berbasis media merupakan alternatif baru bagi individu untuk mengelola dirinya baik dengan masalah medis maupun psikologis yang dapat dilakukan dengan menggunakan buku, kaset audio, video dan selama dekade berikutnya telah berkembang program self-help berbasis komputer yang memanfaatkan komputer atau jaringan internet sebagai media dalam aktifitas bantuan diri.

Bantuan diri ini memiliki tujuan untuk memberikan pemahaman dan pemecahan masalah yang relevan dengan kebutuhan seseorang dalam perkembangannya. Kegiatan bantuan diri dapat dilihat sebagai proses 
bantuan kepada diri sendiri yang memiliki misi yang jelas untuk membantu mengubah beberapa aspek dalam diri sendiri.

Kurtz (2007) juga menjelaskan bahwa bantuan diri memiliki beberapa karakteristik, seperti menanamkan harapan, universalitas dan perasaan memiliki, dukungan, metode penanganan melalui mengajar dan belajar, dan menyampaikan pengetahuan berdasarkan pengalaman.

Menurut Lawrence Elbraum (2008) bantuan diri terdiri dari beberapa jenis, yaitu kelompok bantuan dri, dan media bantuan diri seperti buku, cd dan audio (self-help media).

Menurut Tucker Ladd (1998) bantuan diri adalah salah satu metode yang memiliki beberapa kegunaan, yaitu metode untuk mengubah perilaku, mengubah emosi, mengembangkan ketrampilan dan mengubah pikiran, sikap, konsep diri, motivasi, nilai dan harapan.

\section{BUKU BANTUAN DIRI (SELF- HELP BOOK)}

Anderson et.al dalam Watkins (2007) menyatakan bahwa bantuan diri sulit diartikan tetapi ada konsensus bahwa buku bantuan diri bertujuan untuk dapat membimbing dan mendorong klien untuk melakukan perubahan, sehingga meningkatkan manajemen diri, bukan hanya memberikan informasi saja. Fokus masalah yang dibahas dalam self-help books menargetkan beberapa gangguan tertentu misalnya, serangan panik, depresi, insomnia dan lain-lain. Bentuk bantuan diri cocok dengan terapi perilaku kognitif, dimana responden didorong untuk melaksanakan tugas di antara sesi untuk menentang pemikiran dan perilaku yang tidak membantu.

Starker dalam Ad Bergsma (2007) menyebutkan empat faktor pragmatis yang menjelaskan keberhasilan buku membantu diri sendiri atau manfaat dari buku bantuan diri, yaitu biaya buku bantuan diri yang rendah dibandingkan harus berkonsultasi dengan terapis, aksesibilitas buku yang mudah tersedia sehingga dapat dibaca saat kapanpun, mengatasi masalah tanpa harus diketahui oleh umum atau harus berbicara dengan terapis, memberikan kesempatan bagi pembacanya untuk menjadi bagian dalam grup dalam buku tersebut. Ad Bergsma (2007) membagi tema buku bantuan diri menjadi empat tema yaitu pengembangan, hubungan, mengatasi, dan kepribadian.

Menurut Tucker-Ladd (2006) langkahlangkah bantuan diri terdiri dari sepuluh langkah yaitu, (1) Penulis meminta responden untuk memilih program perbaikan diri. Dalam memilih program perbaikan diri, tidak lebih dari 2 atau 3 pada suatu waktu. (2) Penulis mulai mengumpulkan dan merekam data sesuai dengan tingkat keparahan atau frekuensi masalah responden. (3) Penulis mencoba untuk memahami masalah, bagaimana mengembangkan, penyebab aslinya, dan apa yang menyebabkan hal tersebut berlanjut pada responden. (4) Penulis meminta responden untuk menetapkan tujuan yang realistis. (5) Penulis meminta responden untuk memilih metode bantuan diri (self-help) yang tampaknya paling mungkin untuk digunakan, yaitu "Mengembangkan rencana program". (6) Penulis meminta responden untuk mempelajari langkah-langkah rinci yang terlibat dalam setiap metode bantuan diri (self-help) yang digunakan dan coba rencanakan. (7) Penulis meminta responden melanjutkan seluruh program untuk menilai dan plot kemajuan diri. (8) Jika diperlukan, penulis bersama responden merevisi rencana yang diperlukan, berurusan dengan penolakan terhadap perubahan diri. Menjaga motivasi diri. (9) Penulis meminta responden untuk merencanakan cara mempertahankan keuntungan yang dibuat. (10) Penulis meminta responden membuat catatan efektivitas metode: Apa saja yang dapat bekerja untuk diri sendiri? 
Hal-hal yang perlu diperhatikan dalam pembuatan buku yaitu mengenai komponen apa saja yang dievaluasi atau dinilai setelah produk sudah dicetak. Penyusunan instrumen evaluasi pada penelitian ini dilakukan berdasarkan panduan penilaian buku teks yang dikeluarkan oleh Badan Standar Nasional Pendidikan / BSPN (2006) yang kemudian disesuaikan dengan karakteristik produk. Komponen penilaian buku teks meliputi empat komponen dalam rincian berikut (1) Kelayakan isi: Komponen kelayakan isi ini diuraikan menjadi beberapa subkomponen atau indikator yaitu alignment dengan SK dan KD mata pelajaran, substansi keilmuan dan life skill, wawasan untuk maju dan berkembang, dan keberagaman nilai-nilai sosial. (2) Kebahasaan: Komponen kebahasaan ini diuraikan menjadi beberapa subkomponen atau indikator yaitu keterbacaan, kesesuaian dengan kaida bahasa Indonesia yang baik dan benar, dan logika berbahasa. (3) Penyajian: Komponen penyajian in diuraikan menjadi beberapa subkomponen atau indikator yaitu teknik, materi, dan pembelajaran. (4) Kegrafikan: Komponen kegrafikan ini diuraikan menjadi beberapa subkomponen atau indikator yaitu ukuran/format buku, desain bagian kulit, desain bagian isi, kualitas kertas, kualitas cetakan, dan kualitas jilid.

\section{MASA MENJELANG DEWASA (EMERGING ADULTHOOD)}

Masa menjelang dewasa (emerging adulthood) adalah karakteristik perkembangan individu dalam usia 18 hingga 25 tahun (Arnett, 2005). Masa menjelang dewasa adalah masa perkembangan perpanjangan/ peningkatan usia pernikahan, perpanjangan belajar dengan memasuki pendidikan tinggi, serta perpanjangan dalam masa ketidakstabilan pekerjaan. Arnett (2004) menyatakan bahwa karakteristik yang menandai masa menjelang dewasa yaitu, (1) Eksplorasi identitas, dengan mencoba berbagai kemungkinan, khususnya dalam hal cinta dan pekerjaan.

(2) Ketidakstabilan. (3) Memfokuskan diri.

(4) Periode di antara perasaan. (5) Periode kemungkinan, dengan adanya berbagai kemungkinan, banyak harapan, dan banyak kesempatan untuk mengubah kehidupan mereka.

Masa menjelang dewasa memiliki perkembangan yang unik dalam hal fisik, kognitif, kepribadian dan emosi, serta sosial seperti stres pada masa menjelang dewasa. Masalah yang sering dialami dalam fase masa menjelang dewasa dibedakan menjadi dua yaitu masalah internal (internalizing problems) dan masalah eksternal (externalizing problems).

Menurut Arnett dalam Penney Upton (2012) sebagian besar orang muda di usia ini tidak memandang diri mereka sebagai orang dewasa penuh; namun mereka juga tidak merasa sebagai remaja. Santrock (2008) mengemukakan bahwa tingkat stres dan depresi dialami pada masa menjelang dewasa. Stres dan depresi pada masa menjelang dewasa tersebut, yang membuat beberapa orang mencoba untuk sesuatu hal yang baru salah satunya merokok alasannya karena alasan ingin tahu atau ingin melepaskan diri dari rasa sakit dan kebosanan.

\section{BAHAYA MEROKOK}

Rokok (Ellizabet, 2010) merupakan sebuah silinder kertas yang memiliki ukuran tertentu disetiap negara, sebuah silinder tersebut berisi tembakau yang mengandung nikotin, tar dan zat berbahaya lainnya. Zat yang terkandung dalam rokok tersebutlah yang menyebabkan rokok sangat berbahaya bagi kesehatan dan menimbulkan berbagai macam penyakit seperti contohnya kanker paru-paru atau serangan jantung. Perilaku merokok adalah suatu kegiatan membakar rokok dan menghisap asap rokok tersebut. Rokok mengandung berbagai zat didalamnya, kurang lebih ada 4.000 jenis bahan kimia, 400 zat dapat meracuni tubuh dan 40-43 zat dapat menyebabkan kanker. 
Leventhal dan Clearly (dalam Ellizabet, 2010), mengatakan bahwa terdapat 4 tahap perilaku merokok sehingga menjadi perokok, yaitu Tahap preparotory, initiation, becoming a smoker dan maintenance of smoking. Tipetipe perokok menurut Ellizabet (2010) dibagi menjadi dua yaitu perokok aktif dan perokok pasif. Menurut Non Smoking Right Association jenis-jenis perokok dibedakan menjadi beberapa kategori yaitu first-hand smoker, second-hand smoker, third-hand smoker.

Tingkatan merokok dibagi menjadi 3 yaitu perokok ringan, perokok sedang dan perokok berat. Menurut Sarafino (dalam Ellizabet, 2010), faktor-faktor yang mempengaruhi perilaku merokok ada tiga, yaitu faktor sosial, psikologi, dan genetik. Ogden (dalam Fuadah, 2011) mengklasifikasikan dampak perilaku merokok menjadi dua bagian yaitu dampak positif dan dampak negatif.

Aditama (2001) juga menjelaskan betapa pentingnya penyuluhan kesehatan yang diberikan, hal tersebut juga berguna untuk pencegahan perilaku merokok. Tujuan utama penyuluhan kesehatan adalah agar masyarakat luas mengetahui seluk-beluk sebenarnya tentang bahaya merokok ini, agar mereka dapat mengambil sikap secara tepat. Kalau informasi pada masyarakat luas hanya datang dari iklan rokok maka orang mungkin terkecoh, karena itulah diperlukan pula penyuluhan kesehatan yang luas dengan menggunakan berbagai media yang ada seperti buku. Bantuan bagi mereka yang ingin berhenti merokok atau berkonsultasi, bisa mengunjungi Lembaga Menanggulangi Masalah Merokok (LM3), pelayanan klinik berhenti merokok yang antara lain terdapat di RSUP Persahabatan, Komnas Penanggulangan Masalah Merokok, Yayasan Jantung Indonesia, Wanita Indonesia Tanpa Tembakau, Yayasan Asma Indonesia, dan lainlainnya.

\section{METODE PENELITIAN}

Metode penelitian yang digunakan adalah Penelitian dan Pengembangan (Research and Development). Pada penelitian ini, pelaksanaan penelitian metode $R \& D$ merujuk pada prosedur yang dikembangkan oleh Borg dan Gall (1989). Model penelitian ini bertujuan untuk menghasilkan produk tertentu dan menguji keefektifan produk tersebut.

Penelitian R\&D terdiri dari sepuluh tahap yaitu, penelitian dan pengumpulan informasi, perencanaan, pengembangan format produk awal, validasi produk awal, revisi produk, pengujian, operasional revisi produk, operasional bidang pengujian, revisi produk akhir, dan penyebaran dan laporan. Penelitian yang dilakukan oleh peneliti tergolong dalam penelitian R\&D skala kecil (Small-Scale R\&D), karena penelitian yang dilakukan menggunakan beberapa tahapan saja. Untuk mengatasi masalah keterbatasan yang dimiliki mahasiswa dalam melakukan penelitian $R \& D$ yaitu dengan melakukan proyek skala kecil. Sesuai dengan pernyataan Borg dan Gall, maka peneliti memutuskan untuk membatasi tahapan yang dilakukan, yaitu dari tahap pertama sampai pada tahap kelima, dan berikut adalah tahapannya; penelitian dan pengumpulan informasi; perencanaan; pengembangan format produk awal; validasi produk awal; dan revisi produk.

Hal ini juga dinyatakan pada bab pendahuluan di pembatasan masalah, bahwa peneliti membatasi penelitian pengembangan model hanya pada model hipotetik. Penelitian pemula yang menghasilkan program hipotetik manual kegiatan pelatihan masih memerlukan tindak lanjut oleh peneliti berpengalaman yang memiliki minat terhadap pengembangan produk bertema buku bantuan diri untuk mencegah perilaku merokok.

\section{HASIL PENELITIAN}


ini mengacu pada model penelitian dan pengembangan Borg and Gall, yang dibatasi pada beberapa tahap saja. Tahaptahap tersebut meliputi: (1) Penelitian dan pengumpulan informasi, dalam tahap ini peneliti mengumpulkan informasi dengan cara melakukan analisis kebutuhan. Peneliti menyebarkan angket untuk mengetahui kebutuhan pengguna dalam aspek media visual, unsur visual, kebutuhan bantuan diri dan informasi apa saja yang dibutuhkan dalam buku bantuan diri untuk mengetahui bahaya dari merokok. Responden berjumlah 218 orang terdiri dari delapan fakultas di Universitas Negeri Jakarta. (2) Perencanaan, yaitu peneliti merangkum materi-materi tentang bantuan diri dan informasi tentang bahaya merokok, serta merangkum hasil sumber dari materi tentang bantuan diri dan bahaya merokok setelah itu, peneliti juga menyusun garis besar isi dan materi buku bantuan diri mengenai materi yang ingin dikembangkan menjadi sebuah buku. (3) Pengembangan format produk awal, peneliti membuat kompetensi-kompetensi isi buku bantuan diri yang telah dilakukan pada tahap perencanaan, membuat rancangan materi isi buku dengan desain berisi keterangan seperti tulisan atau teks, gambar, bagan dan lain-lain. Pada tahap ini peneliti juga mulai merancang bentuk serta ukuran buku sesuai studi pendahuluan yaitu $16 \times 23 \mathrm{~cm}$, ukuran huruf 12 , jenis huruf comic sans, merancang sampul buku, merancang isi buku seperti menambahkan beberapa pertanyaan dan lembar kerja agar pembaca tidak hanya mendapatkan informasi saja tetapi pembaca juga dapat menilai dirinya sendiri atau merefleksikan langsung pada dirinya sendiri, menambahkan konten-konten gambar yang menarik perhatian pembaca, mengatur warna tulisan agar mudah dibaca, serta memberikan pen-dahuluan agar pembaca tahu dan paham maksud isi dan tujuan buku bantuan diri ini. (4) Validasi Produk Awal, dalam tahap ini peneliti telah membuat produk secara keseluruhan dan telah dicetak berupa buku, lalu membuat kisi-kisi instrumen uji coba validasi produk dan mencari validator ahli yang akan menguji produk. Hal ini dilakukan untuk mereview produk awal dan memberikan masukan untuk perbaikan buku bantuan diri. Adapun tiga validator ahli yang dipilih oleh peneliti untuk memberikan validasi adalah sebagai berikut:

1. Bapak Cecep Kustandi, M.Pd., selaku dosen jurusan Teknologi Pendidikan Fakultas Ilmu Pendidikan di Universitas Negeri Jakarta sebagai validator ahli media untuk melakukan penilaian terhadap aspek kelayakan kegrafikan yang terdiri dari indikator ukuran buku, desain sampul buku dan desain isi buku.

\begin{tabular}{cccccc}
\hline Aspek & Indikator & Skor & $\begin{array}{c}\text { Total } \\
\text { Skor }\end{array}$ & $\%$ & $\begin{array}{c}\text { Krite- } \\
\text { ria }\end{array}$ \\
\hline & Ukuran & 8 & & & \\
Buku & & & & \\
$\begin{array}{c}\text { Aspek } \\
\text { Kelayakan }\end{array}$ & $\begin{array}{c}\text { Desain } \\
\text { Sampul } \\
\text { Buku }\end{array}$ & 39 & 97 & $80,8 \%$ & $\begin{array}{c}\text { Sangat } \\
\text { Layak }\end{array}$ \\
& $\begin{array}{c}\text { Desain Isi } \\
\text { Buku }\end{array}$ & 50 & & & \\
& & & & \\
\hline
\end{tabular}

Tabel 1 Hasil Validasi Ahli Media

2. Ibu Eka Wahyuni, S.Pd., M.A.A.P.D., selaku dosen jurusan Bimbingan dan Konseling Fakultas Ilmu Pendidikan di Universitas Negeri Jakarta sebagai validator ahli materi untuk melakukan penilaian terhadap aspek penilaian isi, aspek penilaian kelayakan penyajian, dan aspek layanan informasi bahaya merokok.

\begin{tabular}{ccccc}
\hline Aspek & Skor & Total Skor & $\%$ & Kriteria \\
\hline $\begin{array}{c}\text { Aspek } \\
\text { Penilaian Isi } \\
\text { Aspek }\end{array}$ & 28 & & & \\
Penilaian & 13 & & & \\
Kelayak an & & & & \\
Penyajian & & $52,2 \%$ & Layak \\
Aspek & & & & \\
Layanan & & & & \\
Informasi & 11 & & \\
Bahaya & & & \\
Merokok & & & \\
\hline Tanel 2 Hasil Validasi Ahli Materi
\end{tabular}

Tanel 2 Hasil Validasi Ahli Materi 
3. Bapak Asisda Wahyu A.P., M.Hum., selaku dosen jurusan Bahasa Indonesia Fakultas Bahasa dan Seni di Universitas Negeri Jakarta sebagai validator ahli materi untuk melakukan penilaian terhadap aspek penilaian bahasa yaitu indikatornya adalah keterbahasaan.

\begin{tabular}{c|c|c|c}
\hline Aspek & Total Skor & Persentase & Kriteria \\
\hline $\begin{array}{c}\text { Penilaian } \\
\text { Bahasa }\end{array}$ & 31 & $86,1 \%$ & $\begin{array}{c}\text { Sangat } \\
\text { Layak }\end{array}$ \\
\hline
\end{tabular}

Tabel 3 Hasil Validasi Ahli Bahasa

4. Mahasiswa/i Universitas Negeri Jakarta sebagai validator pengguna bertujuan untuk mengetahui keefektifan buku, selain itu untuk mencermati, menilai, memberi masukkan dan memberikan pendapat. Jumlah mahasiswa yang dijadikan validator pengguna yaitu 9 orang.

5. Revisi Produk. Peneliti telah merevisi produk berdasarkan penilaian validatorvalidator ahli yaitu validator media, validator materi, validator bahasa dan validator pengguna. Hasil revisi seperti sampul buku, penambahan ilustrasi, memperinci materi, penambahan materi, penambahan informasi, penambahan lembar kerja, mengganti gambar sesuai undang-undang, penempatan kata dan tanda baca, kurangnya konsistensi penggunaan kata, penggunaan kata sesuai KBBI, pemberian warna pada kalimat, penulisan daftar pustaka, dan penambahan kata motivasi.

\begin{tabular}{ccccccc}
\hline No & $\begin{array}{c}\text { Re- } \\
\text { spon- } \\
\text { den }\end{array}$ & Skor & $\begin{array}{c}\text { Total } \\
\text { Skor }\end{array}$ & $\begin{array}{c}\text { Rata- } \\
\text { rata }\end{array} \%$ & Kriteria \\
\hline 1 & DM & 78 & & & & \\
2 & FA & 78 & & & & \\
3 & WE & 80 & & & & \\
4 & IP & 73 & & & & Sangat \\
5 & DF & 84 & 694 & 77,1 & 87,1 & Layak \\
6 & RZ & 80 & & & & \\
7 & CU & 74 & & & & \\
8 & DK & 84 & & & & \\
9 & AS & 63 & & & \\
\hline \multicolumn{6}{c}{ Tabel 4 Hasil Validasi Pengguna }
\end{tabular}

\section{KESIMPULAN, IMPLIKASI, DAN SARAN}

Berdasarkan hasil penelitian maka dapat disimpulkan bahwa buku bantuan diri tentang bahaya merokok dapat dikatakan layak untuk diujicobakan. Hal ini sesuai dengan hasil penilaian para validator ahli, yaitu: (a) Validator ahli media memberikan hasil persentase sebesar $80,8 \%$ artinya sangat layak. (b) Validator ahli materi memberikan hasil persentase sebesar $72,2 \%$ artinya layak. (c) Validator ahli bahasa memberikan hasil persentase sebesar $86,1 \%$ artinya sangat layak. (d) Validator pengguna dari 9 mahasiswa/i mendapatkan hasil rata-rata persentase sebesar $87,2 \%$ artinya sangat layak.

Buku bantuan diri tentang bahaya merokok juga memiliki manfaat bagi pengguna, antara lain: (1) Membantu menginformasikan serta memberikan pengetahuan baru mengenai bahaya merokok kepada mahasiswa. (2) Dapat membantu mahasiswa yang berkeinginan berhenti merokok. (3) Harga buku yang lebih terjangkau dibandingkan harus berkonsultasi dengan pakar ahli seperti dokter, konselor, psikolog dan lainnya. (4) Buku yang sangat praktis dibawa kemanapun dan dibaca pada saat kapanpun. (5) Buku bantuan diri tentang bahaya merokok dikembangkan sebagai upaya preventif terhadap perilaku merokok mahasiswa. 
Implikasi berdasarkan hasil penelitian yang telah dikembangkan oleh peneliti Buku bantuan diri yang dikembangkan oleh peneliti dapat memberikan informasi serta menambah pemahaman dan wawasan mahasiswa mengenai bahaya merokok dan berguna untuk mencegah atau mengurangi perilaku merokok, namun apabila buku bantuan diri ini tidak disosialisasikan kepada mahasiswa atau masa menjelang dewasa maka pengetahuan mahasiswa akan tetat sama dan tidak bertambah mengenai bahaya merokok. Buku bantuan diri ini dapat menjadi salah satu pengantar sebelum melakukan konseling karena responden / konseli akan diberikan pemahaman dan arahan sehingga menemukan titik masalahnya sehingga dapat dijadikan sebagai salah satu merode dalam membantu menangani masalah baru.

Beberapa saran yang dapat menjadi pertimbangan berdasarkan hasil penelitian ini adalah: (1) Buku bantuan diri bisa digunakan konselor untuk menjadi salah satu media bantuan diri untuk mencegah perilaku merokok atau untuk memberikan informasi dan pengetahuan kepada konseli. (2) Buku bantuan diri tentang bahaya merokok ini tidak hanya disebarkan untuk mahasiswa tetapi bisa juga dikembangkan untuk siswa-siwa SMP dan SMA. (3) Dinas kesehatan, lembagalembaga rokok dan organisasi anti rokok disarankan untuk memberikan penyuluhan bahaya merokok dengan memberikan buku bantuan diri supaya mahasiswa yang malu untuk membagi permasalahannya bisa tetap mendapatkan informasi. (4) Buku bantuan diri tentang bahaya merokok ini bisa dilanjutkan oleh peneliti selanjutnya ke tahap berikutnya yaitu ujicoba supaya dapat dibaca dan digunakan mahasiswa. (5) Bagi peneliti lain diharapkan buku bantuan diri atau penelitian ini dapat lebih dikembangkan dan dijadikan sebagai sumber referensi atau acuan sebagai cara untuk mengetahui pengetahuan yang dimiliki mahasiswa tentang bahaya merokok serta memberikan informasi tentang bahaya merokok. dan (6) Bagi peneliti lanjutan yang tertarik membahas tentang hal yang sama mungkin bisa dilakukan di Universitas Lainnya tidak hanya di Universitas Negeri Jakarta.

\section{DAFTAR PUSTAKA}

Aditama, T.Y. (2001). Masalah Merokok dan Penanggulangannya. Jakarta: Ikatan Dokter Indonesia (IDI).

Arnett, J.J. . (2004). Emerging Adulthood: The Winding Road from Late Teens through the Twenties 1st ed. USA: Oxford University Press.

Arnett, J.J. (2005). The Developmental Context of Substances Use in Emerging Adulthood. The Journal of Drug Issues, 35(2), 1-19.

Arnett, J.J. (2012). Adolescents and Emerging Adulthood: A Cultural Approach. 5th ed. USA: Pearson Education, Inc.

Badan Standar Nasional Pendidikan. (2007). Buletin BNSP. Jakarta

Bergsma, A. (2007). Do Self - Help Books Help?. Journal of Happiness Studies Published, 9 , 341-360.

Kurtz, L.F. (2007). Self Help and Support Groups: A Handbook for Practioners. Sage Publication.

Mackay, J. \& Erikson, M. (2002). The Tobacco Atlas. Switzerland: World Health Organization.

Na'imah, N. (2016). Gambaran Permasalahan Sosial Mahasiswa Universitas Negeri Jakarta (Unpublished undergraduate thesis). Universitas Negeri Jakarta, Jakarta.

Notoatmodjo, S. (2003). Promosi Kesehatan Teori dan Aplikasinya. Jakarta: Rineka Cipta.

Watkins, P. L. (2008). Self-help therapies. In P. L. Watkins \& G. A. Clum (Eds.), Handbook of self-help therapies (pp. 1-24). Mahwah, NJ: Lawrence Erlbaum Associates.

Scollo \& Winstanley. (2015). Tobacco in Australia: Facts and issues. Melbourne: Cancer Council Victoria. 
Tucker Ladd, C.E. (2006). Psychological Self Help. Mental Health Net.

Upton, P. (2012). Psikologi Perkembangan. Jakarta: Erlangga.

Walter, R. B. \& Gall, M.D. (1983). Educational Research: An Introduction (4th Edition). New York: Longman.

Wullur. (2008). Pengetahuan Tentang Rokok. Yogyakarta: Graha Ilmu. 


\section{Lampiran}

\section{Kisi-kisi Instrumen Ahli Media}

Kisi-kisi Instrumen Ahli Materi

\section{ASPEK}

\section{INDIKATOR PENILAIAN}

Aspek Pe- Kesesuaian materi kecemasan sosial dengan tujuan buku

nilaian Isi Kelengkapan materi kecemasan sosial

Keakuratan konsep dan definisi bahaya merokok

Keakuratan contoh pada materi bahaya merokok

Keakuratan lembar kerja yang disajikan

Penerapan

Kemenarikan materi bahaya merokok

Mendorong pembaca untuk mencari informasi lebih jauh

Kesesuaian materi dengan perkembangan ilmu yang dimiliki pembaca

Gambar, diagram dan ilustrasi aktual

$\begin{array}{ll}\text { Aspek } & \text { Keruntutan penyajian materi bahaya merokok } \\ \text { Penilaian } & \text { Contoh kasus dalam buku } \\ \text { Kelayakan } & \text { Keterlibatan pembaca } \\ \text { Penyajian } & \text { Lembar kerja pada akhir pembahasan materi bahaya merokok } \\ & \text { Gambar, diagram dan ilustrasi menarik }\end{array}$

Aspek Menambah pengetahuan pembaca mengenai informasi bahaya merokok

Layanan Terdapat informasi yang membantu pembaca mengekplorasi diri

Informasi

Bahaya Me

rokok

Terdapat informasi yang membantu pembaca menambah wawasan mengenai bahaya merokok 
Kisi-kisi Instrumen Ahli Bahasa

\begin{tabular}{lll}
\hline \multicolumn{1}{c}{ Aspek } & Indikator & \multicolumn{1}{c}{ Pernyataan } \\
\hline Aspek & Keterbahasaan & Ketepatan struktur kalimat \\
Penilaian & Keefektifan kalimat \\
Bahasa & Keterbacaan pesan \\
& Ketepatan penggunaan kaidah bahasa \\
& Sesuai dengan perkembangan intelektual pembaca \\
& Sesuai dengan perkembangan emosional pembaca \\
& Mampu memotivasi pembaca melalui pesan/informa- \\
& si \\
& Keruntutan dan keterpaduan antar kegiatan \\
& Keruntutan dan keterpaduan antar paragraf \\
\hline
\end{tabular}

Kisi-kisi Instrumen Penilaian Responden (Mahasiswa)

\begin{tabular}{|c|c|c|}
\hline $\begin{array}{c}\text { Aspek } \\
\text { Karakteristik } \\
\text { Bantuan Diri }\end{array}$ & Indikator & Pernyataan \\
\hline \multirow[t]{9}{*}{$\begin{array}{l}\text { Karakteristik } \\
\text { Bantuan Diri }\end{array}$} & $\begin{array}{l}\text { Menanamkan } \\
\text { harapan }\end{array}$ & $\begin{array}{l}\text { Dapat membantu dan meningkatkan } \\
\text { situasi ke arah yang lebih baik }\end{array}$ \\
\hline & & Dapat meringankan masalah \\
\hline & $\begin{array}{l}\text { Universalitas dan } \\
\text { perasaan memiliki }\end{array}$ & $\begin{array}{l}\text { Merasa memiliki untuk berada dalam } \\
\text { situasi yang sama dengan orang lain } \\
\text { dan tidak merasa sendiri }\end{array}$ \\
\hline & & $\begin{array}{l}\text { Dapat memiliki kemampuan untuk } \\
\text { membuka diri }\end{array}$ \\
\hline & Dukungan & $\begin{array}{l}\text { Dapat merasa adanya sebuah dukun- } \\
\text { gan }\end{array}$ \\
\hline & & $\begin{array}{l}\text { Dapat merasakan manfaat dari buku } \\
\text { bantuan diri }\end{array}$ \\
\hline & $\begin{array}{l}\text { Metode penanganan } \\
\text { melalui mengajar dan }\end{array}$ & $\begin{array}{l}\text { Dapat memiliki keterampilan menan- } \\
\text { gani permasalahan diri }\end{array}$ \\
\hline & belajar & $\begin{array}{l}\text { Dapat memperoleh penanganan baru } \\
\text { dalam buku bantuan diri tentang ba- } \\
\text { haya merokok }\end{array}$ \\
\hline & $\begin{array}{l}\text { Menyampaikan pengeta- } \\
\text { huan berdasarkan pen- } \\
\text { galaman }\end{array}$ & $\begin{array}{l}\text { Mendapatkan pengetahuan baru dari } \\
\text { pengalaman pribadi orang lain dalam } \\
\text { buku bantuan diri }\end{array}$ \\
\hline
\end{tabular}




\begin{tabular}{|c|c|c|}
\hline Aspek & Indikator & Pernyataan \\
\hline \multirow[t]{15}{*}{$\begin{array}{l}\text { Manfaat Bantu- } \\
\text { an Diri }\end{array}$} & $\begin{array}{l}\text { Metode Mengubah Per- } \\
\text { ilaku }\end{array}$ & $\begin{array}{l}\text { Menyadari perlunya perubahan dalam } \\
\text { perilaku }\end{array}$ \\
\hline & Metode Mengubah Emosi & $\begin{array}{l}\text { Merasa lebih baik setelah membaca } \\
\text { buku bantuan diri }\end{array}$ \\
\hline & $\begin{array}{l}\text { Metode Mengembangkan } \\
\text { Keterampilan }\end{array}$ & $\begin{array}{l}\text { Mendapatkan informasi mengenai } \\
\text { keterampilan baru untuk mengurangi } \\
\text { perilaku merokok }\end{array}$ \\
\hline & & $\begin{array}{l}\text { Mendapatkan informasi mengenai } \\
\text { keterampilan baru untuk mencegah } \\
\text { perilaku merokok }\end{array}$ \\
\hline & & $\begin{array}{l}\text { Mendapatkan informasi mengenai } \\
\text { keterampilan baru untuk membenten- } \\
\text { gi diri dari keinginan untuk kembali } \\
\text { merokok }\end{array}$ \\
\hline & Metode Mengubah & Dapat mencegah atau mengatasi \\
\hline & Pikiran, Sikap, Konsep & pikiran untuk terus merokok atau \\
\hline & Diri, Motivasi, Nilai dan & mencoba untuk merokok \\
\hline & Harapan & $\begin{array}{l}\text { 1. Dapat mengurangi intensitas mer- } \\
\text { okok setelah membaca buku bantuan } \\
\text { diri }\end{array}$ \\
\hline & & $\begin{array}{l}\text { 2. Dapat menegur orang lain yang } \\
\text { merokok di tempat umum }\end{array}$ \\
\hline & & $\begin{array}{l}\text { 3. Dapat menolak ajakan orang lain } \\
\text { untuk merokok }\end{array}$ \\
\hline & & $\begin{array}{l}\text { Dapat menjadi pribadi yang lebih } \\
\text { sehat tanpa rokok }\end{array}$ \\
\hline & & $\begin{array}{l}\text { Merasa termotivasi untuk mencegah } \\
\text { atau mengurangi perilaku merokok } \\
\text { setelah membaca buku bantuan diri }\end{array}$ \\
\hline & & $\begin{array}{l}\text { Dapat mengetahui perilaku atau } \\
\text { pikiran yang harus dirubah berkaitan } \\
\text { dengan bahaya merokok }\end{array}$ \\
\hline & & $\begin{array}{l}\text { Ingin menjadi pribadi lebih baik (be- } \\
\text { bas asap rokok) setelah menggunakan } \\
\text { buku bantuan diri }\end{array}$ \\
\hline
\end{tabular}

Daftar Isi Buku Bantuan Diri Tentang Bahaya Merokok 
Pendahuluan

Daftar Isi

Bagian 1. Fenomena Tentang Merokok

Bagian 2. Rokok
A. Sejarah Singkat Rokok
B. Apa Itu Rokok dan Perilaku Merokok?
C. Kandungan Rokok
D. Tahapan Perilaku Merokok
E. Tipe Perokok
F. Tingkatan Merokok
G. Faktor-faktor yang Mempengaruhi Perilaku Merokok
H. Dampak Perilaku Merokok

Bagian 3. Stop Merokok !
A. Rokok Teman atau Musuh
B. Apakah kamu ingin berhenti merokok?
C. Strategi Mengatasi atau Mencegah Merokok
D. Tips Merencanakan Untuk Berhenti Merokok
E. Cara Berhenti Merokok Secara Sistematis
F. Sekarang atau Tidak Selamanya
G. Lembaga Rujukan
Daftar Pustaka 